\title{
Using the Residual-Income Stock Price Valuation Model to Teach and Learn Ratio Analysis
}

\author{
Robert F. Halsey
}

\begin{abstract}
This article provides an overview of the residual-income stock price valuation model and demonstrates its use in interpreting the DuPont return on equity $(\mathrm{ROE})$ decomposition. The model provides theoretical support for the DuPont model's focus on ROE and aids in understanding the implications of the price-tobook and price-earnings ratios. I conclude with an application of the model in the valuation of Nordstrom, Inc.
\end{abstract}

\section{INTRODUCTION}

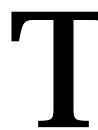

he trend toward increasing reliance on consulting services by CPA firms has fostered a number of changes in accounting curricula toward a broader set of core competencies in accounting graduates. ${ }^{1}$ Among these are a greater understanding of the factors that drive total common equity value and the ability to develop and analyze data to assist managers in maximizing sharehol der value. ${ }^{2}$ The study of ratio analysis provides a case in point. Students must now not only learn the definition of financial ratios, but must also begin to appreciate the linkage between financial ratios, firm valuation, corporate strategy, and the firm's markets in order to spot value-increasing opportunities.

The residual-income valuation model provides a useful framework in which to conduct this discussion. It defines total common equity value in terms of the book value of stockholders' equity and net income determined in accordance with GAAP, and thus is particularly well suited to support instruction of ratio analysis. This article provides an overview of the residual-income stock price valuation model and demonstrates its use in interpreting the DuPont analysis of return on equity (ROE).

1 See the AAA/AECC monographs available on the AAA web site at http://www.rutgers.edu/Accounting/raw/ aaa/facdev/aecc.htm, and the AICPA Report of the Special Committee on Assurance Services available on the AICPA web site at http://www.aicpa.org for a general overview of trends in accounting education.

2 Klein (2000) documents that business valuations have proven a significant growth area for 78 percent of the Top 100 accounting firms, and Fuller (1999) reports that 27 CPA firms have joined together to provide business valuation and litigation services, with combined revenues greater than any single existing business valuation firm.

Robert F. Halsey is an Assistant Professor at Babson College.

Thecomments of Mark Bauman, Frank Heflin, David E. Stout (editor), J ohn Hill (associate editor), and anonymous revi ewers are gratefully acknowledged. 
The rest of the paper is organized as follows. I present an overview of the model in the next section, followed by sections relating to its use in a discussion of ratio analysis, examining the implications of the model for interpretation of the price-to-book and price-earnings ratios, and an analysis of the behavior of ROE over time. Finally, I demonstrate the application of the model using an estimate of the market value of Nordstrom, Inc. as an example.

\section{The Residual-Income Stock Price Valuation Model $^{3}$}

The residual-income stock price valuation model has received considerable academic attention during the past several years. It is theoretically equivalent to the discounted "free-cash-flows-to-equity" model taught in finance courses, as well as the original dividend discount model from which both are derived. ${ }^{4}$ The model expresses total common equity value (P) as the sum of the book value of stockholders' equity (BV) and the present value of expected residual-income (RI), as follows: ${ }^{5}$

$$
\mathrm{P}_{\mathrm{t}}=\mathrm{BV}_{\mathrm{t}}+\sum_{\tau=1}^{\infty}(1+\mathrm{r})^{-\tau}\left[\hat{\mathrm{R}}_{\mathrm{t}+\tau}\right]
$$

where $P_{t}$ is total common equity value, $B V_{t}$ is the book value of shareholders' equity, $r$ is the cost of equity capital, $R I_{t}$ is residual-income, $R I_{t}=I_{t}-\left(r * B V_{t-1}\right), I_{t}$ is net income after tax, ^ denotes expected value, and $t$ is the present time period. ${ }^{6}$ In this model, $\mathrm{RI}$ is defined as the difference between reported net income

3 A more detailed summary of the concepts presented in this section can be obtained from the author or by consulting the original works cited (viz., Ohlson 1995; Feltham and Ohlson 1995; Palepu et al. 2000;

White et al. 1998; Damodaran 1994; Pratt et al. 1996).
4 The original dividend discount model is expressed symbolically as: $P_{t}=\sum_{\tau=1}^{\infty}(1+r)^{-\tau} \hat{d}_{t+\tau}$, where $P$ is total common equity value at time $t, r$ is the cost of equity capital, $d$ is dividends, and $\wedge$ denotes expected value. The model defines total common equity value as the present value of expected dividends. Given an assumed clean surplus relation (e.g., $B V_{t}=B V_{t-1}+I_{t}-d_{t}$; see footnote 6 ) and the definition of $R I$ (e.g., $R I_{t}$ $\left.=I_{t}-r * B V_{t-1}\right)$, the RI model defines dividends in terms of BV and RI as follows, $d_{t}=(1+r) B V_{t-1}-B V_{t}+$ $\mathrm{RI}_{\mathrm{t}}$. Substituting this definition for dividends into the dividend discount model yields the expression in equation (1). From the statement of cash flows, the "free-cash-flows-to-equity" model defines dividends in terms of free-cash-flows-to-equity and is expressed symbolically as follows, $P_{t}=\sum_{\tau=1}^{\infty}(1+r)^{-\tau} \hat{c}_{t+\tau}$, where $P$ is total common equity value and $\mathrm{c}$ is free-cash-flows-to-equity (net cash flow from operations, less capital expenditures, plus the net change in debt). Free-cash-flows-to-equity represent the operating cash flows of the business net of investment in working capital and fixed assets required to support the business, and net of changes in debt. These cash flows are, thus, available to be paid out as dividends. Since both the RI and free-cash-flows-to-equity models are derived from dividends, they are theoretically equivalent, and both are theoretically equivalent to the original dividend discount model.

5 Total common equity value is the market value of the firm's common equity shares. The expression for $\left(P_{t}\right)$ in equation (1) yields the market value of the firm's total equity at timet (Ohlson 1995). If the firm has issued preferred stock, then the value of the preferred shares is subtracted from total common equity value to yield the value of the common shares. For ease of exposition, I assume that only common shares have been issued. Total common equity value, book value of shareholders' equity, and residual-income can be expressed either in total or per share amounts.

6 The model assumes a clean surplus relation; that is, the change in the book value of stockholders' equity is equal to net income (loss) less dividends (e.g., $\left.B V_{t}=B V_{t-1}+I_{t}-d_{t}\right)$. As a result, net income $\left(I_{t}\right)$ should technically be viewed as comprehensive income per SFAS No. 130. Comprehensive income is defined as net income plus changes in stockholders' equity, other than from transactions with stockholders, that are not recognized in the income statement. These include changes in the market value of available-for-sale securities, foreign currency translation adjustments, the minimum pension liability adjustment, and gains (losses) on derivative instruments. 
(I) and the product of (BV) and the firm's cost of equity capital (r). This latter product is the level of income that would be expected for the firm given the book value of its shareholders' equity and the riskiness of its industry. RI can be positive or negative. As a result, if the firm is expected to report abnormally positive income, then its total common equity value will be greater than the book value of stockholders' equity and the converse if expected profits are abnormally low. ${ }^{7}$

This model is equivalent to the discounted "free-cash-flows-to-equity" (DCF) model commonly taught in finance courses. Both are derived from the underlying assumption that total common equity value is equal to the present value of expected dividends. The free-cash-flow model merely defines dividends in terms of free cash flows and the residual-income model defines them in terms of residual earnings (see footnote 4).

A considerable amount of research has been conducted during the past several years to compare the ability of the RI and DCF valuation approaches to predict common stock price. On balance, the RI model has been shown to be more accurate than the DCF or the original dividend discount models in estimating stock prices. ${ }^{8}$ Aside from a possible advantage in pricing, however, the RI valuation model provides a useful framework within which to learn the subject of ratio analysis. It is to this subject that I now turn.

\section{Implication of the Residual-Income Stock Price Valuation Model for Ratio Analysis}

Traditional ratio analysis utilizes the DuPont model to disaggregate the return on common equity (ROE) into its return-on-assets (ROA) and financial leverage (LEV) components, as follows: ${ }^{9}$

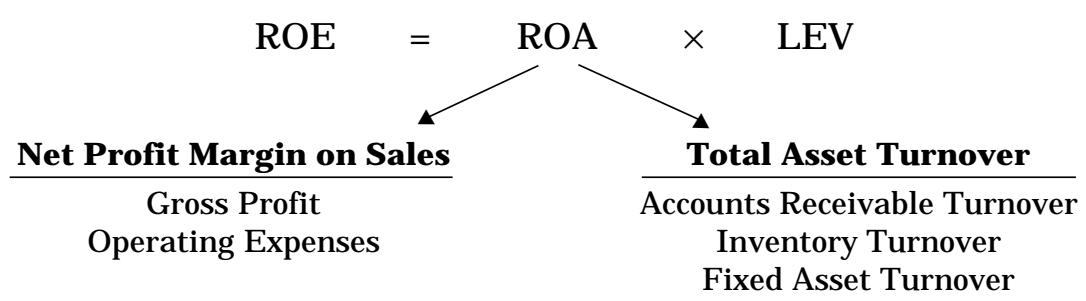

\footnotetext{
7 Abnormal income will arise if the firm earns a rate of return on shareholders' investment (ROE) that is greater than the cost of equity capital. This will arise, for example, if the firm has made positive net present value investments. The excess of price over the book value of stockholder's equity (internally generated goodwill) is the result of the expectation that the firm will realize returns in excess of the cost of equity capital, and will be able to realize these returns over an ever-increasing investment base.

8 See Bernard (1994, 1995), Francis et al. (2000), Frankel and Lee (1998), and Penman and Sougiannis (1998). These papers compare the DCF and RI models using methodology commonly found in practice. Lundholm and O'Keefe (2000) argue that the two models should yield consistent results and that the superiority of RI results from incorrect implementation of the DCF model.

9 To simplify the discussion, I define (I) as net income after-tax, (ROE) as I/average book value of stockholder's equity, and (ROA) as I/average total assets. Although both the RI and DuPont ratio analysis frameworks can be adapted to the use of comprehensive income after the payment of preferred dividends, the added complexity does not enhance the insights gained in using RI to understand the implications of the DuPont model; therefore, the simpler definitions are used in this paper.
} 
Following this definition, the analysis proceeds to investigate the factors affecting net profit margin on sales (gross profit margin and operating expense control) as well as those affecting total asset turnover (accounts receivable turnover rate, inventory turnover rate, and fixed asset turnover rate). The equation also demonstrates that ROE is increasing in LEV (average total assets/average book value of stockholders' equity). To investigate the implications of LEV on financial solvency, the analysis is typically complemented with a discussion of liquidity (current and quick ratios) and solvency (debt and times-interest-earned ratios).

The RI valuation model provides a particularly rich setting in which to explore the reason for the emphasis on ROE and to demonstrate algebraically several implications of the analysis that are often presented in textbooks without derivation:

- total common equity value $\left(P_{t}\right)$ is increased providing the expected ROE $>r$;

- $P_{t}$ is increased as the firm increases financial leverage providing the return on net operating assets (RNOA) is greater than the cost of the debt (the "trading on the equity" concept); and

- aside from LEV, the core driver of firm value is the interaction between profit margin and turnover.

I now discuss each of these concepts in turn.

\section{The Focus on ROE}

From equation (1), we see that the RI model estimates total common equity value $\left(P_{t}\right)$ as: $P_{t}=B V_{t}+($ Present value of expected $R I)$. The key determinant of the relation between total common equity value $\left(P_{t}\right)$ and the book value of stockholders' equity $\left(\mathrm{BV}_{\mathrm{t}}\right)$, then, is the expected level of RI . Expressed al gebraically, RI $=I-(r * B V)$, where I is reported net income, $r$ is the firm's cost of equity capital, and BV is the beginning-of-period book value of shareholders' equity. RI can also be expressed in ratio form as follows:

$$
\mathrm{I}-(\mathrm{r} * \mathrm{BV})=\left(\frac{\mathrm{I}}{\mathrm{BV}}-\frac{\mathrm{r} * \mathrm{BV}}{\mathrm{BV}}\right) * \mathrm{BV}=(\mathrm{ROE}-\mathrm{r}) * \mathrm{BV}
$$

where ROE is the return on common equity (i.e., ROA * LEV). This implies that $\left(P_{t}\right)$ increases as long as $(R O E)>r$ and, thus, provides a reason for selecting ROE as the primary focus of our analysis within the context of the DuPont framework.

As long as $(R O E)>r,\left(P_{t}\right)$ is increased by growing the investment base (BV), either through additional common equity investment or the retention of earnings.

From an operating perspective, firms can increase $\left(P_{t}\right)$ by increasing profitability for the same capital investment, reducing the capital required to generate a given level of profitability, or growing their capital base while maintaining the same or increasing their return on capital employed. ${ }^{10}$ The model thus suggests

\footnotetext{
10 Positive RI can result from sustainable competitive advantage (positive net present value projects, as discussed in footnote 7) and from "conservative" accounting such as expensing R\&D (see, Palepu et al. 2000, 11-4,11-6; Feltham and Ohlson 1995; Ohlson 2000). I focus on sustainable competitive advantage in this paper to highlight the management implications of the model, and to be consistent with the intuition of the DuPont model of ROE disaggregation that focuses on efficiency and productivity (see also Stewart 1991).
} 
that managers should focus on becoming more efficient and more productive in their use of corporate resources. ${ }^{11}$

\section{Trading on the Equity}

The "trading on the equity" concept seeks to explain why firms use financial leverage, but is often presented in textbooks without derivation. Using the RI framework, it is straightforward to demonstrate that ROE can be expressed as a function of the return on net operating assets (RNOA) and financial leverage (FLEV) as follows:

$$
\mathrm{ROE}=\mathrm{RNOA}+(\mathrm{FLEV} * \mathrm{SPREAD})
$$

where FLEV is financial leverage as measured by the debt-to-equity ratio (as opposed to the average total assets/average book value of stockholders' equity in equation (2)), and SPREAD is RNOA less the after-tax cost of debt. ${ }^{12}$ The intuition of equation (4) is as follows: stockholders will benefit if the firm purchases an asset with an expected return of, say, 8 percent and finances the purchase with debt costing 6 percent, since the excess return ( 2 percent after payment of the interest to the debtholders) accrues to them.

${ }^{11}$ This is similar to the Economic Value Added (EVA $\left.{ }^{\circledR}\right)$ concept. The EVA formula defines market value as follows: $M V=$ capital + present value of future EVA, where $E V A_{t}=$ operating profit $t_{t}-r_{w}{ }^{*}$ capital $_{t-1}$. The underlying structure of the valuation model is the same as RI. EVA redefines capital from the book value of stockholders' equity to net operating assets (net working capital + long-term operating assets) and defines income as NOPAT (net operating profit after tax $=\mathrm{NI}+$ after-tax interest expense). The focus is the return on net operating assets (RNOA; see footnote 12) and the target for the return is the weighted average cost of capital $\left(r_{w}\right)$. As long as the firm earns a return on operating assets that is above this level, it creates economic value. Other adjustments to the RI model include, for example, the add-back to capital of the cumulative amortization of goodwill, and the capitalization of operating lease assets that have been written off or not recorded under GAAP, but are considered by EVA proponents to reflect the true level of capital utilized in the business. NOPAT is similarly adjusted to add back goodwill amortization and other GAAP-related expenses not considered to be "true" operating expenses. See Stewart (1991) for a discussion.

$$
\begin{aligned}
12 \mathrm{ROE} & =\frac{\mathrm{I}}{\mathrm{BV}} \\
& =\frac{\mathrm{OI}-\mathrm{NFE}}{\mathrm{BV}} \\
& =\frac{\mathrm{OI}}{\mathrm{BV}}-\frac{\mathrm{NFE}}{\mathrm{BV}} \\
& =\left(\frac{\mathrm{OA}}{\mathrm{BV}} * \mathrm{RNOA}\right)-\left(\frac{\mathrm{NFO}}{\mathrm{BV}} * \mathrm{NBC}\right) \\
& =\left(\frac{(\mathrm{BV}+\mathrm{NFO})}{\mathrm{BV}} * \mathrm{RNOA}\right)-\left(\frac{\mathrm{NFO}}{\mathrm{BV}} * \mathrm{NBC}\right) \\
& =\mathrm{RNOA} *\left(1+\frac{\mathrm{NFO}}{\mathrm{BV}}\right)-\left(\frac{\mathrm{NFO}}{\mathrm{BV}} * \mathrm{NBC}\right) \\
& =\mathrm{RNOA}+\left(\frac{\mathrm{NFO}}{\mathrm{BV}} * \mathrm{RNOA}\right)-\left(\frac{\mathrm{NFO}}{\mathrm{BV}} * \mathrm{NBC}\right) \\
& =\mathrm{RNOA}+\frac{\mathrm{NFO}}{\mathrm{BV}}(\mathrm{RNOA}-\mathrm{NBC}) \\
& =\mathrm{RNOA}+(\mathrm{FLEV} * \mathrm{SPREAD})
\end{aligned}
$$


Equation (4) follows directly from the definition of ROE and the decomposition of assets and liabilities into operating-related and financial-related activities. It implies that ROE can be increased in two ways: (1) increase RNOA; and (2) increase FLEV as long as RNOA > net after-tax cost of debt. It al so highlights the importance of distinguishing between the portion of ROE related to the firm's operations and that related to the firm's financing strategy.

\section{Common Stock Value Drivers}

Given the decomposition of ROA into profit margin and turnover in the traditional DuPont analysis, the factors that are directly relevant to the creation of total common equity value by increasing ROE, then, include the following:

1. Net profit margin on sales

2. Turnover of average total assets

3. LEV (as long as RNOA > net after-tax cost of debt, i.e., as long as financial leverage is favorable)

Since net profit margin (net income/sales) and total asset turnover (sales/average total assets) rates are interrelated, it is difficult to predict the effect of a marginal increase in one of these variables on the firm's market value. For example, if the firm faces a downward sloping demand curve, then attempting to increase the profit margin through an increase in the market price of the firm's products results in a reduction in the quantity of the product demanded. The effect of this price increase on sales and the asset turnover rate, therefore, cannot be determined without first specifying the demand curve. Likewise, the effect on

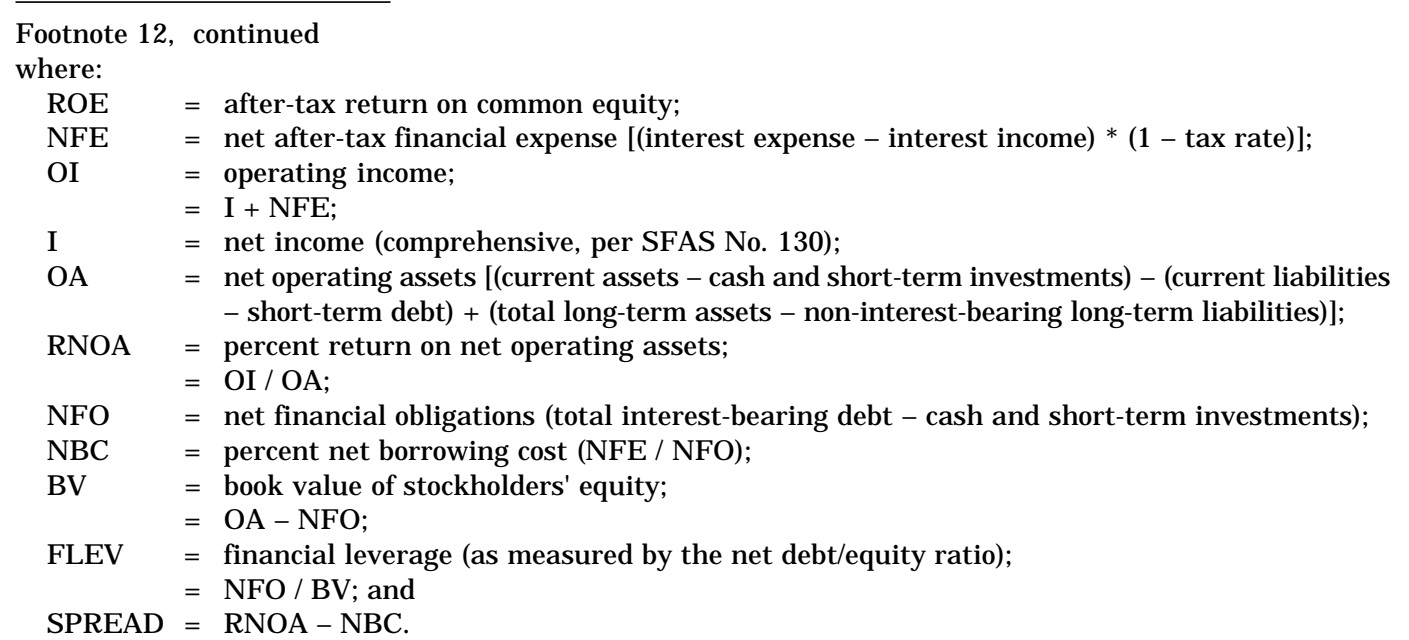

All balance sheet variables are reported as of the beginning of the period (see Nissim and Penman [1999] for further discussion). Note: The model presented above utilizes net financial obligations rather than total liabilities and, as a result, FLEV is not the same formula as LEV used in the body of the paper. I have employed FLEV to describe this debt-to-equity form of (net) financial leverage and LEV to describe the form of financial leverage utilized by the DuPont model (average total assets/average total stockholders' equity). 
common equity value of an increase in asset turnover requires specification of its effect on the profit margin, which requires knowledge of the firm's cost function. ${ }^{13}$

The task facing corporate managers is to increase both profit margins and turnover rates through greater efficiency and productivity. F or example, managers must find ways to reduce the cost of their products (without sacrificing quality) or corporate overhead so that profit margins will increase for reasons other than an increase in the price of the firm's products. Likewise, managers must continually find ways to reduce the amount of invested capital. This can be accomplished, for example, by employing more efficient manufacturing methods to reduce work-in-process inventories.

The drivers of ROE (NPM, TAT, and LEV) should be the focal point of the analysis. They involve no economic assumptions as the relations between income and balance sheet amounts are a direct result of algebraic manipulation of the basic RI valuation model (see, for example, equation (3) and footnote 12). As a result, these drivers hold under all economic conditions and are constant across all companies regardless of the particular accounting methods employed. ${ }^{14}$

Ratio analysis is often presented in textbooks as a collection of formulae with no unifying structure. The RI valuation model provides instructors with a direct link between profitability and turnover ratios and the creation of common equity value through the use of an accounting-based valuation model.

\section{Interpretation of Current Period Price-to-Book (P/B) and Price/Earnings (P/E) Ratios}

The RI model also provides insight into the inferences that can be drawn from price-to-book (P/B) and price-earnings (P/E) ratios. ${ }^{15}$ Penman (1996) demonstrates that $P / B$ is related to future $\mathrm{RI}$ and the expected growth rate in book value. ${ }^{16}$ Note that the current level of profitability (ROE) is not a factor in the P/B ratio.

To achieve a high $\mathrm{P} / \mathrm{B}$ ratio, therefore, managers must not only earn an abnormally high ROE, but also must realize these extraordinary earnings over an everincreasing investment base (BV). The "normal" P/B ratio of 1.0 is realized only in the event that the firm is not expected to realize positive residual income. If the firm is not expected to earn the required rate of return that its shareholders expect, then its $P / B$ ratio will be less than 1.0 .

13 The effect of an increase in the market price of the firm's products on total common equity value can be shown to depend on the partial derivative of the asset turnover rate with respect to the selling price of the product, which is, in turn, a function of the demand curve. Likewise, the effect of an increase in the asset turnover rate on firm value is a function of the partial derivative of the profit margin with respect to the asset turnover rate and is a function of the firm's cost function.

14 For example, "conservative" accounting depresses the book value of stockholders' equity, but this is exactly offset by an increase in expected RI, leaving stock price unaffected (see Lundholm [1995] for a discussion, and Bauman [1999] for an empirical example).

${ }^{15}$ I use the terms price-to-book ratio $(P / B)$ and price-earnings ratio $(P / E)$ as these terms are commonly used in practice and are as discussed in Penman (1996). Utilizing the terminology employed in the paper, these relate to the total common equity value-to-book value of stockholders' equity and total common equity value-to-net income, respectively.

16 From equation (1), $\mathrm{P}_{\mathrm{t}}=\mathrm{BV}_{\mathrm{t}}+\sum_{\tau=1}^{\infty}(1+\mathrm{r})^{-\tau}\left[\hat{\mathrm{R}} \mathrm{I}_{\mathrm{t}+\tau}\right]$. Dividing by $\mathrm{BV}$, the total common equity value-to-book value of stockholders' equity (P/B) ratio is, therefore, equal to $\frac{P_{t}}{B V_{t}}=1+\sum_{\tau=1}^{\infty}\left(\frac{R O E_{t+\tau}-r}{(1+r)^{\tau}}\right)\left(\frac{B_{t+\tau-1}}{B V_{t}}\right)$. Thus, $P / B$ is related to future RI (ROE - r) and the expected growth rate in book value. See also Damodaran (1994) and White et al. (1998). 
Penman (1996) further demonstrates that the P/E ratio is related to both current and expected profitability. ${ }^{17}$ If current profitability (ROE) is viewed as "Iow" relative to expected profitability, then the P/E ratio will be high; and if current profitability is viewed as "high" relative to expected profitability, then the P/E ratio will be low. The $P / E$ ratio, therefore, reflects the market's perception of the extent to which earnings are viewed as transitory and are likely to revert to a higher or lower level in the future. Finally, if RI is expected to be 0 , then the P/E ratio will be at a "normal" level of $(1+r) / r$, where $r$ is the cost of equity capital (e.g., for a 10 percent cost of equity capital, the P/E multiple is 11 ). High (low) P/E ratios relative to their "normal" levels are a function of the extent to which expected RI is higher (lower) than current RI.

It is important to note that the $\mathrm{P} / \mathrm{E}$ is determined by the relation between current and future profitability. One cannot infer unambiguously the level of future profitability from this ratio. For example, a firm with poor future prospects, but even poorer current performance, would still report a high P/E ratio. Conversely, a firm with positive expected RI might still report a low P/E ratio if current levels of profitability are higher than the levels the market projects.

The interaction between $P / B$ and $P / E$ ratios provides interesting insights into market expectations that have been impounded into stock prices, as summarized in Exhibit 1. Firms with high $\mathrm{P} / \mathrm{B}$ and high $\mathrm{P} / \mathrm{E}$ ratios (cell I) are those with positive expected RI and net income (I) that is expected to increase from current levels. These are the highest-performing (high-growth) companies. Conversely, low P/B with low $\mathrm{P} / \mathrm{E}$ ratios (cell IV) indicate negative expected residual-income and future earnings less than current levels. Clearly, these firms are facing serious difficulties as their existing investments are not expected to earn a return in excess of the cost of capital and profitability is expected to decline from current levels. Firms with high P/B and low P/E (cell II) are expected to report positive residual profits but falling earnings.

${ }^{17}$ Given clean surplus accounting (e.g., $B V_{t}=B V_{t-1}+I_{t}-d_{t}$; see footnote 6), if we add dividends $\left(d_{t}\right)$ to both sides of the $\mathrm{RI}$ total common equity value equation (1), and divide by net income $\left(\mathrm{I}_{\mathrm{t}}\right)$, then $\frac{\mathrm{P}_{\mathrm{t}}+\mathrm{d}_{\mathrm{t}}}{\mathrm{I}_{\mathrm{t}}}=1+\frac{\mathrm{BV}_{\mathrm{t}-1}}{\mathrm{I}_{\mathrm{t}}}+\sum_{\tau=1}^{\infty} \frac{\mathrm{RI}_{\mathrm{t}+\tau}}{(1+\mathrm{r})^{\tau} \mathrm{I}_{\mathrm{t}}}=1+\frac{1}{\mathrm{ROE}_{\mathrm{t}}}+\sum_{\tau=1}^{\infty} \frac{\mathrm{RI}_{\mathrm{t}+\tau}}{(1+\mathrm{r})^{\tau} \mathrm{I}_{\mathrm{t}}}$. The second term on the right-hand side is the inverse of $\mathrm{ROE}$. So, the total common equity value-to-net income $(\mathrm{P} / \mathrm{E})$ ratio is related to both current and expected profitability.

EXHIBIT 1

Interpretation of $\mathrm{P} / \mathrm{B}$ and $\mathrm{P} / \mathrm{E}$ Ratio Combinations

$\frac{\text { High P/B }}{\text { I }}$

(high-performing companies)

High P/E expected positive RI

increasing income

II

(declining companies)

expected positive RI

decreasing income
Low P/B

III

(improving companies)

expected negative RI

increasing income

IV (poor-performing companies)

expected negative RI

decreasing income 
Thesefirms are still generating productive (positive net present value) investments, but are in a state of decline. Firms with low P/B and high P/E ratios (cell III) are unable to generate positive net present value investment opportunities, but profitability is expected to increase from current levels. These are firms that are improving their operations, but have not yet resolved their operating difficulties.

So, how many companies fit the profiles outlined above? Penman (1996) analyzes the frequency that $\mathrm{P} / \mathrm{B}$ and $\mathrm{P} / \mathrm{E}$ ratios are above (below) their historical medians and reports the following data for the period 1968-1985:

\begin{tabular}{lcc} 
& High P/B & Low P/B \\
\cline { 2 - 2 } High P/E & $32.8 \%$ & $16.7 \%$ \\
Low P/E & $17.1 \%$ & $33.4 \%$
\end{tabular}

About one-third of publicly traded firms are strong performers with RI expected to improve from current levels. In addition, a third of the firms are facing significant challenges and are not expected to report positive RI . Approximately 17 percent of firms are troubled but improving, and an equal number are performing well but are expected to decline in profitability.

\section{Prediction of ROE and its Components}

Implementation of the RI valuation model involves projecting return on equity (ROE) and book values (BV) for a specified forecast horizon, followed by the estimation of the terminal value. One question facing the analyst relates to the period of the forecast horizon. Generally, 5-10 years is chosen. This is not as arbitrary at it might first appear, however. Since no total common equity value is added beyond the point at which $\mathrm{RI}=0$ (that is, when ROE $=r$ ), if we knew the approximate period of time over which RI $>0$ (ROE $>r$ ) is expected to occur, then we could use that period of time for the forecast horizon.

Penman (1991) provides some evidence on the period over which abnormal ROE can be expected to be realized. For each year during 1969-1985 he formed portfolios of firms based on their level of ROE. He then tracked the performance of these firms over a number of years subsequent to portfolio formation and reports the results shown in Exhibit 2.

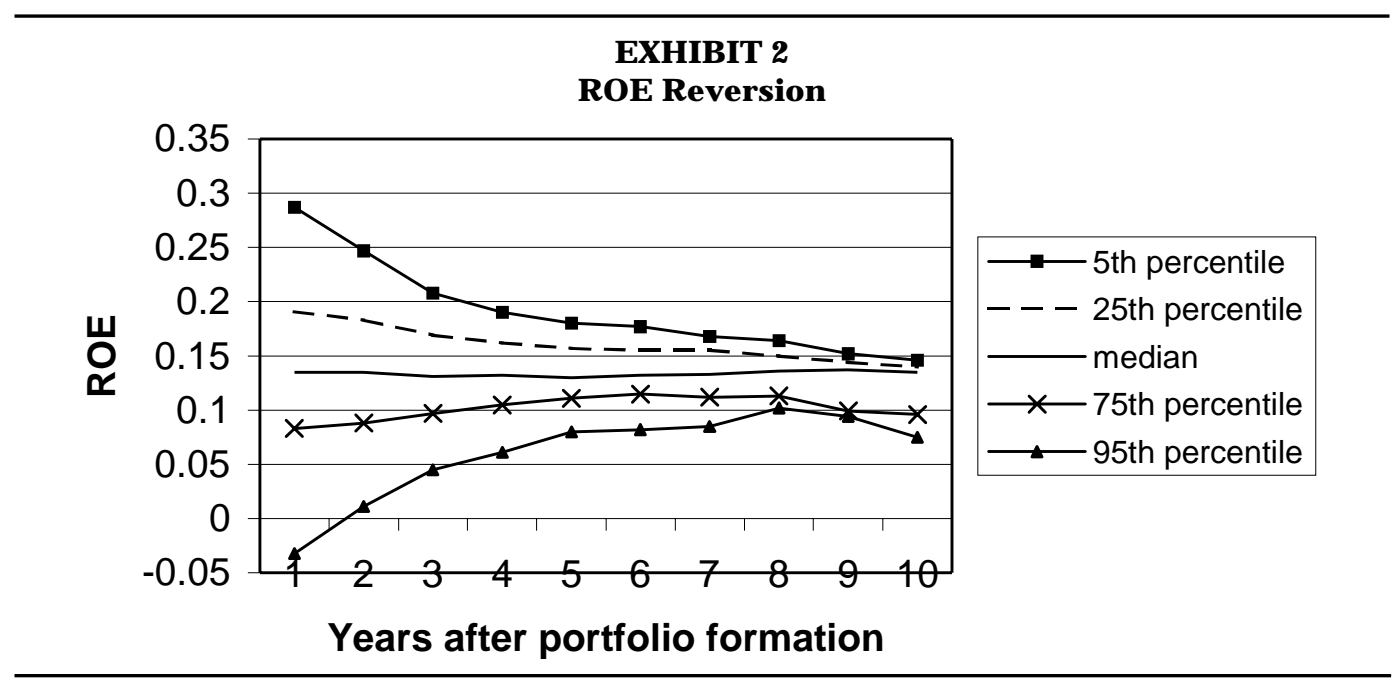


Abnormal ROEs appear to revert to an average return that is close to the longrun stock returns for the market and, thus, appear to revert to the average cost of equity capital ( $r$ ) over time. In addition, most of the reversion appears to be completed by eight years. Given a shock that drives ROE either above or below its historic average, forces begin to dissipatethat shock over time. Positiveabnormal earnings are competed away, and negative shocks are corrected (or the firm ceases to exist). The five to ten-year benchmark for the forecast horizon appears to be justified by average market forces that limit the persistence of the shock to abnormal earnings.

The DuPont ratio analysis framework in equation (2) decomposes ROE into net profit margin on sales, total asset turnover, and financial leverage. Since total common equity value is a function of projected ROE (equation (3)), a critical task facing the analyst is to forecast values for these component ratios during the forecast horizon. A number of studies have attempted to quantify the determinants of the ROE mean reversion and have documented that turnover rates and other financial ratios exhibit mean reversion over time, possibly to some industry norm. That is, when shocks occur that drive these ratios away from their equilibrium values, they slowly revert over time to their previous levels. ${ }^{18}$ Furthermore the speed of the reversion depends on economic factors such as the types of products the firm sells (durable and nondurable), barriers to entry in the industry, firm size, and capital intensity. ${ }^{19}$

Halsey and Soybel (2001) document differences in reversion rates for the components of ROE. Most of the reversion in ROE is due to reversion in profit margins, as financial leverage and total asset turnover change slowly over time. There are, however, differences in the component reversion rates across industries and as a function of the difference between the level of the component ratio and the industry average. The prediction of future earnings and turnover rates, therefore, is contextual and simple averages across all firms may not yield accurate forecasts.

\section{CONCLUSION}

Accruals are an integral part of instruction in financial reporting. Although abuses exist and are the subject of considerable attention in the financial press, earnings and book values determined in accordance with GAAP have consistently proven to be more valuerelevant than cash flows. ${ }^{20}$ It is not necessary, therefore, to undo accruals in order to evaluate the performance of a company and estimate the market value of its common equity. The residual-income (RI) valuation model is an earnings-based approach. It affords accountants with a framework to analyze company performance within the context of accrual accounting.

The RI framework also provides accounting instructors with a rich setting in which to discuss the economic determinants of total common equity value. The object of the analysis is future residual earnings. It is often instructive to explore business factors that affect future profitability. In that context, ROE can be viewed not as the sole object of the analysis, but as an indicator reflecting underlying business dynamics. Students are thus led to investigate the strategic and tactical decisions made by firms and their impact on future residual income.

\footnotetext{
${ }^{18}$ See Lev (1969), Frecka and Lee (1983), Davis and Peles (1993), Lee and Wu (1988), and Halsey and Soybel (2001).

19 See Lev (1983).

${ }^{20}$ See, for example, Dechow (1994) and Subramanyam (1996).
} 


\section{Valuation Example \\ Nordstrom, Inc.}

\section{APPENDIX}

The following is an example of the financial statement analysis and valuation methodologies discussed above as applied to Nordstrom, Inc.

Nordstrom, Inc. is one of the nation's fashion specialty retailers. Its product mix includes apparel, shoes, and accessories for men, women, and children. Nordstrom is known for the "quality" of its retail shopping experience (that results from a sales staff known for customer service) and its significant investment in-store infrastructure (source: Nordstrom, Inc. 1998 Annual Report). Its common stock is traded on the NYSE (J WN).

Key financial ratios for Nordstrom, and industry medians, as of FY98 ( $\mathrm{J}$ anuary, 1999) are as follows:

\begin{tabular}{|c|c|c|c|c|c|c|}
\hline & $\begin{array}{c}\text { Return on } \\
\text { Equity } \\
\text { (ROE) }\end{array}$ & $\begin{array}{l}\text { Net Profit } \\
\text { Margin } \\
\text { (NPM) }\end{array}$ & $\begin{array}{l}\text { Total Asset } \\
\text { Turnover } \\
\text { (TAT) }\end{array}$ & $\begin{array}{l}\text { Avg. } \\
\text { Assets/ } \\
\text { Avg. } \\
\text { Equity } \\
\text { (LEV) }\end{array}$ & $\begin{array}{l}\text { Price/ } \\
\text { Book } \\
\text { (P/B) }\end{array}$ & $\begin{array}{c}\text { Price/ } \\
\text { Earnings } \\
(P / E)\end{array}$ \\
\hline Nordatrom & $14.81 \%$ & $4.11 \%$ & 1.68 & 2.15 & 4.53 & 29.79 \\
\hline Industry median & $14.81 \%$ & $4.03 \%$ & 2.44 & 1.79 & 2.38 & 16.00 \\
\hline
\end{tabular}

Nordstrom's ROE for FY98 (14.81 percent) was at the industry median. Although its NPM (4.11 percent) was slightly above the industry median, its TAT (1.68) was significantly less; thus, it appears that its ROE was maintained by higher-than-average LEV (2.15).

As of FY98, Nordstrom's above-average P/B (4.53) and P/E (29.79) ratios reflected the market's expectation of continued improvement. Specifically, the P/B greater than 1.0 indicates the market's forecast of positive RI. TheP/E ratio greater than 10.80 indicates market expectations of Nordstrom's ROE rising above current levels. ${ }^{21}$ In sum, market expectations are positive as of the company's year-end.

Nordstrom has demonstrated the following historical performance:

\begin{tabular}{|c|c|c|c|c|}
\hline & $\begin{array}{l}\text { Return on } \\
\text { Equity } \\
\text { (ROE) } \\
\end{array}$ & $\begin{array}{c}\text { Net Profit } \\
\text { Margin } \\
\text { (NPM) } \\
\end{array}$ & $\begin{array}{c}\text { Total Asset } \\
\text { Turnover } \\
\text { (TAT) } \\
\end{array}$ & $\begin{array}{l}\text { Avg. Assets/ } \\
\text { Avg. Equity } \\
\text { (LEV) } \\
\end{array}$ \\
\hline FY94 & $16.17 \%$ & $5.21 \%$ & 1.70 & 1.82 \\
\hline FY95 & 11.94 & 4.01 & 1.60 & 1.85 \\
\hline FY96 & 10.19 & 3.31 & 1.64 & 1.88 \\
\hline FY97 & 12.63 & 3.84 & 1.74 & 1.89 \\
\hline FY98 & 14.81 & 4.11 & 1.68 & 2.15 \\
\hline
\end{tabular}

Its ROE has increased during the last three years from a low of 10.19 percent, due primarily to an increase in its NPM and its LEV.

Although the estimation process can become quite complex, in its simplest form we can utilize the three determinants of ROE (NPM, TAT, and LEV) together with an estimate of future sales to accomplish this task. The following table estimates the value of Nordstrom's common stock as of its J anuary, 1999 year end. It is constructed as follows:

${ }^{21}$ The "normal" P/E ratio, assuming a cost of equity capital of 10.2 percent is $1.102 / 0.102=10.80$. 
1. Sales are projected at the 1998-1999 growth rate of 3.6 percent. Since ROE is at the industry median, no reversion is predicted. Therefore, net profit margin, total asset turnover rate, and financial leverage are assumed to remain at 1999 levels. These are utilized to project the income statement, the bal ance sheet, and the statement of cash flows as follows (for ease of exposition, ratios are computed on year-end values, not averages):

a. Net income is computed from sales and the NPM.

b. Assets are computed from sales and the TAT.

c. Liabilities are computed from total assets and LEV.

2. The cost of equity capital $(r)$ is estimated at 10.2 percent, utilizing the CAPM framework and a beta of 0.97 (available from analysis sources like Bloomberg, Hoovers, or Global Access); a risk-free rate of 4.72 percent (the ten-year bond yield as of the date of the valuation); and a market risk premium of 5.75 percent. Thus, $r=4.62 \%+0.97(5.75 \%)=10.2 \%$. This is used to discount residual-income.

3. Assuming a perpetuity of the terminal-year RI and a growth of 3.63 percent, the terminal value (TV) is computed as:

$$
\mathrm{TV}=\frac{\$ 95.6}{(0.102-0.036)} * 62 \cong \$ 895.3 \text { (difference due to rounding). }
$$

\begin{tabular}{|c|c|c|c|c|c|c|c|c|c|}
\hline & \multicolumn{3}{|c|}{ Historical } & \multicolumn{5}{|c|}{ Forecast Horizon } & $\mathrm{Yr}$ \\
\hline & $\mathbf{F Y}$ & 1998 & 1999 & 2000 & 2001 & 2002 & 2003 & 2004 & 2005 \\
\hline Sales growth & & & $3.63 \%$ & $3.63 \%$ & $3.63 \%$ & $3.63 \%$ & $3.63 \%$ & $3.63 \%$ & $3.63 \%$ \\
\hline Net Profit Margin & & & & & & & & & \\
\hline (NPM) & & & $4.11 \%$ & $4.11 \%$ & $4.11 \%$ & $4.11 \%$ & $4.11 \%$ & $4.11 \%$ & $4.11 \%$ \\
\hline Total Asset & & & & & & & & & \\
\hline Turnover (TAT) & & & 1.61 & 1.61 & 1.61 & 1.61 & 1.61 & 1.61 & 1.61 \\
\hline LEV (TA/TE) & & & 2.37 & 2.37 & 2.37 & 2.37 & 2.37 & 2.37 & 2.37 \\
\hline Cost of equity (r) & & & & $10.2 \%$ & & & & & \\
\hline
\end{tabular}

(in \$ millions)

Sales

Net income (I)

Total assets

$4851.6 \quad 5027.9 \quad 5210.4 \quad 5399.5$

$5595.5 \quad 5798.7 \quad 6009.2$

6227.3

$\begin{array}{llll}186.2 & 206.7 & 214.2 & 222.0\end{array}$

$\begin{array}{llll}230.1 & 238.4 & 247.1 & 256.0\end{array}$

Total Stockholder's

$\begin{array}{llllllll}2881.8 & 3115.4 & 3228.5 & 3345.7 & 3467.1 & 3593.0 & 3723.4 & 3858.6\end{array}$

Equity (BV)

1475

$1316.7 \quad 1364.4 \quad 1414.0$

$1465.3 \quad 1518.5 \quad 1573.6$

1630.7

Residual Income Computation

Net Income (I)

Beginning Equity (BV)

Required Equity Return ( $r$ )

Expected Earnings ( $r * B V)$

Residual Income (RI $=I-r * B V)$

Discount factor ( $r=0.102)$

$\begin{array}{cccccc}214.2 & 222.0 & 230.1 & 238.4 & 247.1 & 256.0 \\ 1316.7 & 1364.4 & 1414.0 & 1465.3 & 1518.5 & 1573.6 \\ 10.2 \% & 10.2 \% & 10.2 \% & 10.2 \% & 10.2 \% & 10.2 \% \\ 134.3 & 139.1 & 144.2 & 149.4 & 154.9 & 160.5 \\ 80.0 & 82.9 & 85.9 & 89.0 & 92.2 & 95.6 \\ 0.91 & 0.82 & 0.75 & 0.68 & 0.62 & \end{array}$

Present Value of RI

Cumulative Present Value of RI

$\begin{array}{lllll}72.6 & 68.2 & 64.2 & 60.3 & 56.7\end{array}$

$\begin{array}{lllll}72.6 & 140.8 & 205.0 & 265.3 & 322.0\end{array}$

Terminal Value of RI

Beg. book value of stockholders' equity (BV)

Value of common equity $\left(P_{t}\right)$ 
The results presented above yield a stock price per share $\left(p_{t}\right)$ estimate of $\$ 17.83$ as of J anuary 1999 (the date of the FY98 Annual Report). As of that date, Nordstrom's stock was trading at $\$ 42$.

The market price significantly in excess of the computed price can be due to a number of factors. Perhaps the market is utilizing a cost of equity capital less than the assumed rate of 10.2 percent. ${ }^{22}$ Assuming an equity premium of 2.5 percent, for example, reduces the cost of equity capital to 7.2 percent $(4.72 \%+[0.97$ * 2.5\%]) and increases the computed market price to $\$ 32.80$, holding ROE constant. Another alternative is that the market is projecting a higher ROE, perhaps due to higher expected net profit margins or total asset turnover rates. For example, varying NPM in the RI valuation model presented above, a market price of $\$ 42$ is consistent with an increase of Nordstrom's NPM to 9 percent from its current level of 4.12 percent, holding $(r)$ constant. Similar alternatives can also be explored for total asset turnover and financial leverage.

In sum, the current market price reflects a market expectation of Nordstrom's ROE considerably higher than historical levels, perhaps in combination with a lower cost of equity capital. It should be noted, however, that during the following year (FY 99) N ordstrom's stock fell to a range of \$18-24 per share, as these higher returns were not realized.

${ }^{22}$ Gebhardt et al. (2000) suggest that the equity risk premium may, in fact, be as low as 2.5 percent. 


\section{TEACHING NOTES}

I assign this article to M.B.A. students in non-el ective financial-reporting and elective financial statement analysis courses at the beginning of the term. Its purpose is to introduce a basic understanding of firm valuation that can then be utilized as a framework for discussion as the course progresses. Course topics are then discussed within this valuation framework, demonstrating what information is revealed by a thorough understanding of financial statements that in turn provides insights into the projection of profitability and cash flow. I have found that students value learning within a context that teaches them how to apply the information.

I also break students into groups to prepare a company analysis on a company of their choice, utilizing the concepts described in the article. This project has been very well received by students as it is a "real-world" application of the theoretical concepts discussed in class and gives them a sense for the "art" of financial statement analysis beyond the mechanics of ratio computation.

One objective of the project is to practice the mechanics of valuation utilizing the residual-income (RI) framework and to reinforce the connection between ratio analysis, the company's operating strategy, and accounting policies. The project asks students to look beyond the financial ratios to explore underlying business fundamentals and corporate strategy. The written report is kept to a five-page maximum, excluding exhibits, to encourage students to focus their discussion.

In addition to preparation of a written analysis and valuation report, student groups present their findings to the class in a 15-minute presentation. The presentation time is short to encourage students to focus their discussion on key points of the analysis. I end the presentations with a discussion of the differences noted across the company financial footprints (DuPont ROE decomposition), and their relation to the various industries and corporate strategies represented in the analyses.

The following are general guidelines I provide to the students for use in the company analysis and valuation project:

1. Develop the DuPont ROE decomposition for the company and its competitor. The analysis should decompose ROE into net profit margin (NPM), total asset turnover (TAT), and financial leverage (LEV) for the most recent year and the previous two years. Within the profit margin section, further examine gross margin and operating expenses. Within the turnover section, further examine receivable, inventory, payables, and fixed asset turnover rates. Besure to eliminate any transitory items (unusual income or expense items that are unlikely to be repeated in the future), and make appropriate balance sheet adjustments, before analyzing trends.

2. Describe the differences between the two financial footprints. Do the differences result from strategic differences, or differences in markets or marketing strategy? What insights do you gain about your company from the comparison? Discuss the company's use of financial leverage. Is the stockholders' equity insufficiently leveraged to maximize the investment? Has the company taken on too much risk to realize its level of ROE? Compare the company's leverage against its competitor or industry averages to get a sense of its relative leverage. 
3. Review the notes to the financial statements and describe the company's accounting policies insofar as they affect its financial performance. Look at the annual reports of several other companies in your industry to see if your company has adopted any accounting policies that are unusual.

4. What are the strengths and weaknesses within the ROE decomposition analysis? Does the company have a sustainable competitive advantage that will allow it to perpetuate an abnormally high ROE? If so, what is it and why can it not be easily competed away? For a company with financial weaknesses, does the company have a viable plan to correct its problems at a reasonable cost?

5. Perform a valuation of the company using the residual-income (RI) approach. To project ROE, begin with a comparison of its profit margin, turnover, and financial leverage with its primary industry average, and justify your projected rate of mean reversion. Discount the projected residual earnings at the firm's cost of equity capital ( $r$ ) under the capital asset pricing model (CAPM). Using this approach:

$$
r=r_{f}+\beta\left(r_{m}-r_{f}\right)+r_{\text {size }}
$$

where $r_{f}$ is the ten-year Treasury bond yield as of the valuation date, $\beta$ is the company's beta (widely available from analysis sources like Bloomberg or Global Access), $\left(r_{m}-r_{f}\right)$ is the market risk premium (typically estimated at 5-6 percent), and $r_{\text {size }}$ is the additional return (if any) required for smaller firms (typically 2-3 percent) (see Palepu et al. [2000] for a discussion).

6. Discuss the difference between your valuation of the company and the stock price as of the date of its annual report. Examine the company's current price/ earnings $(\mathrm{P} / \mathrm{E})$ and price-to-book $(\mathrm{P} / \mathrm{B})$ ratios. What do these ratios imply about the market's expectations of future performance? Can you pinpoint any differences in assumptions that contribute to the difference, if any, between your expectations and that of the market? For this part you may also want to examine analysts reports and/or articles in the financial press.

\section{REFERENCES}

Bauman, M. P. 1999. I mportance of reported book value in equity valuation. J ournal of Financial Statement Analysis (Winter): 31-40.

Bernard, V. 1994. Accounting-based valuation models, determinants of markto-book ratios, and implications for financial statement analysis. Working paper, U niversity of Michigan.

-_- 1995. The Feltham-Ohlson framework: Implications for empiricists. Contemporary Accounting Research 11 (2): 733-748.

Damodaran, A. 1994. Damodaran on Valuation: Security Analysis for Investment and Corporate Finance. New York, NY: J ohn Wiley \& Sons, Inc.

Davis, H. Z., and Y. C. Peles. 1993. Measuring equilibrating forces of financial ratios. The Accounting Review 68 (4): 725-747.

Dechow, P. M. 1994. Accounting earnings and cash flows as measures of firm performance: The role of accounting accruals. J ournal of Accounting and E conomics 18 (1): 3-42.

Feltham, G., and J . Ohlson. 1995. Valuation and clean surplus accounting for operating and financial activities. Contemporary Accounting Research 11 (2): 689-732. 
Francis, J ., P. Olsson, and D. R. Oswald. 2000. Comparing the accuracy and explainability of dividend, free cash flow, and abnormal earnings equity value estimates. J ournal of Accounting Research (Spring): 45-70.

Frankel, R., and C. M. C. Lee. 1998. Accounting valuation, market expectation, and cross-sectional returns. J ournal of Accounting and Economi cs 25 (3): 283-319.

Frecka, T. J ., and C. F. Lee. 1983. Generalized financial ratio adjustment processes and their implications. J ournal of Accounting Research (Spring): 308-316.

Fuller, J . 1999. CPA firms form financial consulting group. Accounting Today 13 (6): 4.

Gebhardt, W. R., C. M. C. Lee, and B. Swaminathan. 2000. Toward an implied cost-of-capital. Working paper, Cornell University.

Halsey, R. F., and V. E. Soybel. 2001. Mean reversion of ROE components. Working paper, Babson College.

Klein, M. 2000. Niche, specialties stuff Top 100 coffers. Accounting Today 14 (5): A10-A11.

Lee, C. F., and C. Wu. 1988. Expectation formation and financial ratio adjustment processes. The Accounting Review (April): 292-306.

Lev, B. 1969. Industry averages as targets for financial ratios. J ournal of Accounting Research (Autumn): 290-299.

_-_. 1983. Some determinants of time-series properties of earnings. J ournal of Accounting and Economics 5: 31-48.

Lundholm, R. 1995. A tutorial on the Ohlson and Feltham-Ohlson models: Answers to some frequently-asked questions. Contemporary Accounting Re search 11 (2): 749-762.

- - - and T. O'K eefe. 2000. Reconciling value estimates from the discounted cash flow model and the residual-income model. Working paper, University of Michigan.

Nissim, D., and S. Penman. 1999. Ratio analysis and equity valuation. Working paper, Columbia University.

Ohlson, J . 1995. Earnings, book values, and dividends in equity valuation. Contemporary Accounting Research 11 (2): 661-688.

_-_. 2000. Positive (zero) NPV projects and the behavior of residual earnings. Working paper, New York University.

Palepu, K. G., P. M. Healy, and V. L. Bernard. 2000. Business Analysis \& Valuation. 2nd edition. Cincinnati, $\mathrm{OH}$ : South-Western College Publishing.

Penman, S. 1991. An evaluation of accounting rate-of-return. J ournal of Accounting, Auditing, and Finance(Spring): 233-256.

- - - 1996. The articulation of price-earnings and market-to-book ratios and the evaluation of growth. J ournal of Accounting Research (Autumn): 235259.

- - - , and T. Sougiannis. 1998. A comparison of dividend, cash flow, and earning approaches to equity valuation. Contemporary Accounting Research (Fall): 343-384.

Pratt, S. P., R. F. Reilly, and R. P. Schweiths. 1996. Valuing a Business. 3rd edition. New York, NY: McGraw-Hill.

Stewart, G.B. 1991. The Quest for Value: the EVA ${ }^{\circledR}$ Management Guide. New York, NY: Harper Collins Publishers, Inc.

Subramanyam, K. R. 1996. The pricing of discretionary accruals. J ournal of Accounting and Economics (22): 249-282.

White, G. I., A. Sondhi, and D. Fried. 1998. The Analysis and Use of Financial Statements. Second edition. New York, NY: J ohn Wiley \& Sons. 